\title{
Introduction to Case Studies in Entrepreneurship
}

After attending many conferences on entrepreneurship and talking to colleagues at other universities, it occurred to the authors that there was a need for a book that would contain current entrepreneurship cases of special interest to students. Most entrepreneurship and small business textbooks contain few, if any, cases that an instructor can dig into with students and illustrate important theories or topics from the course. That realization was the impetus for writing this casebook.

Most of the cases in this book have been class tested, and often the instructor's manual was revised after this experience. The Warby Parker, Etsy and Magnolia and the Silos cases were entrepreneurial endeavors the students already know something about; and they enjoyed expressing their views on challenges the entrepreneurs faced. The Lily Jade, Nightlight Donuts and Revival Restaurant cases were entirely new to students, but they were intrigued by the way in which each of these entrepreneurs recognized an opportunity for a new business.

We hope you will enjoy developing your students' critical thinking skills as you explore these new cases with them.

Online resources to supplement the book can be accessed at: https://www.e-elgar.com/ textbooks/reed?stage $=$ Stage. 